\title{
Indicating the Role of Geological Conditions in Shaping the Hareer Anticline, Iraqi Kurdistan Region
}

\author{
Varoujan K. Sissakian1, Ala A. Ghafur ${ }^{1}$, Nadhir Al-Ansari ${ }^{2 *}$, Hawkar A. Abdulhaq ${ }^{3}$, \\ Hassan 0. Omer ${ }^{1}$
}

${ }^{1}$ Department of Natural Resources Engineering and Management, School of Science and Engineering, University of Kurdista Hewler, Erbil, Iraq

${ }^{2}$ Lulea University of Technology, Lulea, Sweden

${ }^{3}$ Szeged University, Szeged, Hungary

Email: f.khajeek@ukh.edu.krd, ala.abdulla@ukh.edu.krd, ^nadhir.alansari@ltu.se, abdulhaq.hawkar.ali@geo.u-szeged.hu, h.othman@ukh.edu.krd

How to cite this paper: Sissakian, V.K., Ghafur, A.A., Al-Ansari, N., Abdulhaq, H.A. and Omer, H.O. (2021) Indicating the Role of Geological Conditions in Shaping the Hareer Anticline, Iraqi Kurdistan Region. Open Journal of Geology, 11, 696-711. https://doi.org/10.4236/ojg.2021.1112034

Received: November 15, 2021

Accepted: December 27, 2021

Published: December 30, 2021

Copyright (c) 2021 by author(s) and Scientific Research Publishing Inc. This work is licensed under the Creative Commons Attribution International License (CC BY 4.0).

http://creativecommons.org/licenses/by/4.0/

\begin{abstract}
The Hareer anticline is within the High Folded Zone, facing southwards towards the Low Folded Zone. Both zones are part of the Outer Platform of the Arabian Plate. Moreover, both zones are part of the Zagros Fold-Thrust Belt located within the Zagros Foreland Basin. Although the Hareer anticline is a double plunging anticline oriented in a NW-SE trend, both plunges are abnormal. The northwestern plunge is gradually passing to the southwestern limb of the Pirat anticline; although there is a very shallow syncline in between them, giving a right-hand en-echelon form to the plunge. Whereas, the southeastern plunge disappears between the Kamosk anticline located southeast wards and the Shakrook anticline is located southwards. Both the Hareer and the Kamosk anticlines are thrusted over the Shakrook anticline by means of two long thrust faults that run almost parallel to the Hareer anticline. It is clearly observed that the anticline is growing northwest wards; according to the recognized geomorphological and structural features. High-Quality satellite images were interpreted to elucidate the abnormal form of the Hareer anticline. The interpreted data and different types of geomorphological features including the estimation of the rate of stream incision were checked in the field.
\end{abstract}

\section{Keywords}

Hareer Anticline, En-Echelon Plunge, Zagros Foreland Basin, Thrust Fault 


\section{Introduction}

The Iraqi Kurdistan Region includes tens of anticlines of different types and shapes located in different parts of the region. They are oriented in a NW-SE trend at the eastern part of the region and change to an E-W trend; approximately west of latitude $\mathrm{E} 43^{\circ} 30^{\prime}$. This change in the trend of the anticlines is attributed to the main trends of the Zagros and Taurus ranges, respectively. In tectonically active areas such as the Iraqi Kurdistan Region, which forms the northeastern part of the Arabian Plate; the lateral growth of anticlines is a very common phenomenon [1]-[7]. The lateral growth of the anticlines in the Iraqi Kurdistan Region is still active, as witnessed from different geomorphological and structural forms covered by different authors. The anticlines; accompanied with synclines are developed due to a clockwise movement of the Arabian Plate and its collision with the Eurasian (Iranian) Plate, forming a convergent tectonic plate boundary [8] [9]. The exerted forces due to the plates collision have developed regional trust faults and other local thrusts, reverse and normal faults; some of them are few kilometers in length, others attaining $30 \mathrm{~km}$ in length; like the one along the southwestern limb of the Hareer anticlines [10].

Anticlines can have abnormal structural shapes due to overturning, over-thrusting, en-echelon plunging, doming, extensive erosion and due to exposure of different rock types with different competencies (example: [2] [11] [12]). The Hareer anticline is one of those anticlines which has an abnormal structural shape.

The Hareer anticline is located in the central part of the Iraqi Kurdistan Region (Figure 1), and it forms part of the main chain of mountains which form the southern limits of the High Amplitude Mountains Province [10]. Hareer town is located along the most western part of the southwestern limb of the Hareer anticline which is about $50 \mathrm{~km}$ north of Erbil city. The town can be reached by a paved road from Erbil as well as by many other routes, whereas the anticline can be accessed through an unpaved road, which runs through the hinge zone of the anticline.

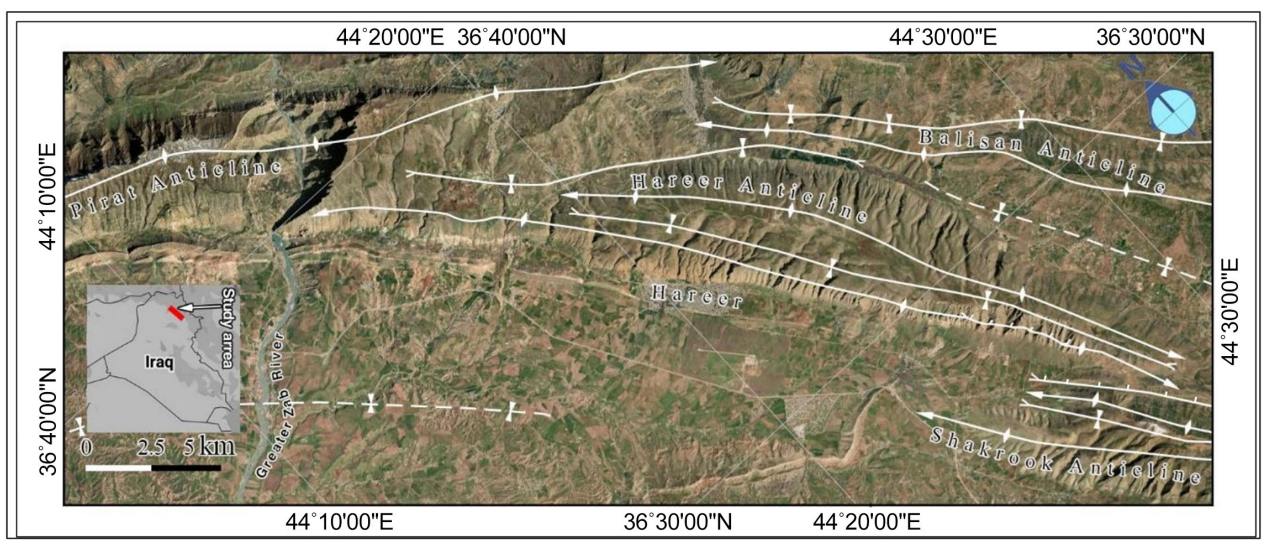

Figure 1. Satellite image showing the location of the studied area, the Hareer anticline and the surrounding anticlines. 
The aim of this research is to elucidate the abnormal shape of the Hareer anticline and the status of its both plunges which are also unusual plunges, and to discuss the reasons for the development of these abnormal forms depending mainly on Campbell [13], Burbank and Anderson [11] and Fossen [12]. Moreover, to estimate the rate of the incision of the streams which dissect the anticline, through studying the abandoned alluvial fans following the Exposure Dating Method [14].

No special studies are available which deal especifically with the Hareer anticline; however, many studies are available in which the Hareer anticline was included. Among them are De Vera et al. [15] studied the Zagros Fold-Thrust Belt in the Kurdistan Region and considered the Hareer anticline as a continuous anticline with the existing east-west wards anticlines. Moreover, in a cross-section, they considered two subsurface thrust faults to exist along both plunges of the anticline. However, they do not present the long thrust fault which runs along the southwestern limb of the anticline. Burtscher et al. [16] conducted tectonic geomorphological investigations of antiforms using differential geometry at the Permam anticline, in northern Iraq and considered the Hareer anticline as a normal double plunging anticline. Sissakian and Fouad [10] updated the geological map of Iraq including the Hareer anticline. Sissakian and Abdul Jabbar [17] studied some of the transversal gorges in the Kurdistan Region and considered the streams which dissect the Hareer anticline as Neotectonic activity. Sissakian et al. [18] studied the origin and development of the Gulley Ali Beg gorge and concluded that the stream which flows in the studied gorge was originally flowing across the Hareer anticline and was diverted north-wards, due to the lateral growth of the Hareer anticline. Omar and Syan [19] constructed a structural model of the Hareer anticline and considered it as a double plunging asymmetrical anticline, dissected by three strike slipfaults. Le Garzica et al. [20], conducted a regional balanced and restored sections, across the northwestern part of the Zagros Fold-and-Thrust Belt in the Kurdistan Region of Iraq and a kinematic model that illustrates the evolution of the belt since Late Cretaceous time. They considered the Hareer anticline as a box fold characterized by short, steep dip domains along the flanks of the anticline. Moreover, they described the anticline as "whaleback anticline geometry which is highlighted by serial topographic profiles".

\section{Materials and Methods}

In order to fulfill the aim of this research work, different materials were used; such as geological maps of 1:100,000 and 1:250,000 scales, topographical maps at a scale of 1:100,000 and 1:20,000, many published articles, books and reports which deal either with the Hareer anticline or with the geology of the surrounding area.

High quality satellite images were interpreted to recognize the role of the geomorphological and structural features which contributed to creating abnormal shapes of the anticline, especially in the north western plunge and to indi- 
cate the reasons for development of the present structural form of the Hareer anticline. Field work was carried out to check the interpreted data from the satellite images, to measure the thicknesses of terraces and alluvial fans, and height differences between stream levels and base of terraces and/or alluvial fans.

Geological and topographical maps were used to indicate different structural, geomorphological and topographical data of the Hareer anticline, with special attention paid to both plunges and the abnormal shape of the anticline. Satellite images were interpreted to recognize indications that have contributed to the development of the abnormal shape of the Hareer anticline. Moreover, to recognize different geomorphological and structural forms which indicate a lateral growth of the anticline. In this concern, we have emphasized the opinion of Keller and Pinter [14] and Ramsey et al. [4]. River terraces and abandoned alluvial fans were recognized from the satellite images by visual interpretation and were carefully investigated in the field to indicate their heights above nowadays streams levels and the thicknesses of each discovered level. Accordingly, the rates of deposition and incision during the Holocene Period were indicated.

\section{Geological Setting}

\subsection{Structural Geology and Tectonics}

The Hareer anticline is NW-SE trending, a double plunging anticline with a box shape due to the existence of two anticlinal axes with a very shallow syncline between them (Figure 1). Towards the north, there are the Pirat and Balisan anticlines, with a long syncline in between (Figure 1). The northwestern plunge of the Hareer anticline being of right hand en-echelon type; with the Pirat anticline, whereas the southeastern plunge is dissected by a thrust fault which runs parallel to the southwestern limb and disappears between the Shakrook and Kamosk anticlines which are located south and southeast of the Hareer anticline, respectively. This thrust fault has caused the disappearance of the synclinal axis between the Hareer and Shakrook anticlines (Figure 1). Moreover, the thrust fault has caused the overturning of the Pila Spi Formation along the southwestern limb of the Hareer anticline (Figure 2). Another thrust fault runs within the southwestern limb of the anticline. It has caused the disappearance of part of the anticlinal axis (Figure 3 and Figure 4). The northwestern plunge of the Hareer anticline is flat (Figure 5) and there is a preponderance of a flat plunge, and a very gentle saddle between the Hareer and Pirat anticlines.

Along the main axis of the anticline and northwards, a very gentle antiform exists giving a box shape to the anticline with a maximum width of $4.8 \mathrm{~km}$, whereas the width of the northwestern and southeastern parts does not exceed $1 \mathrm{~km}$. Moreover, along the eastern part of the southwestern limb of the anticline, a low angle thrust fault occurs. It runs parallel to the axis and has caused the overriding part of the exposed rocks of the north-eastern limb, on those of the southwestern limb. Accordingly, forming very steep cliffs and the disappearance of the Qamchuqa Formation and the lower part of the Bekhme Formation (Figure 3).

Tectonically, Hareer anticline is located within the High Folded Zone of the 
Outer Platform [21], which is a part of the Arabian Plate. The area is also within the Zagros Fold-Thrust Belt (ZFTB); inside the Zagros Foreland Basin. The Arabian Plate is in collision with the Eurasian (Iranian) Plate. As a result of the collision of both plates, successive zones of deformation have progressively advanced south-westward along the western ZFTB [1] [8] [21] [22] [23] [24]. This advancement has resulted in the horizontal and vertical movements along the ZFTB due to the movement of basement faults [23] [25]. Accordingly, different types of folds were developed; some of them are of the abnormal type; like the Hareer anticline which shows a very gentle and long northwestern plunge, whereas the main mass of the anticline has a whale-back shape.

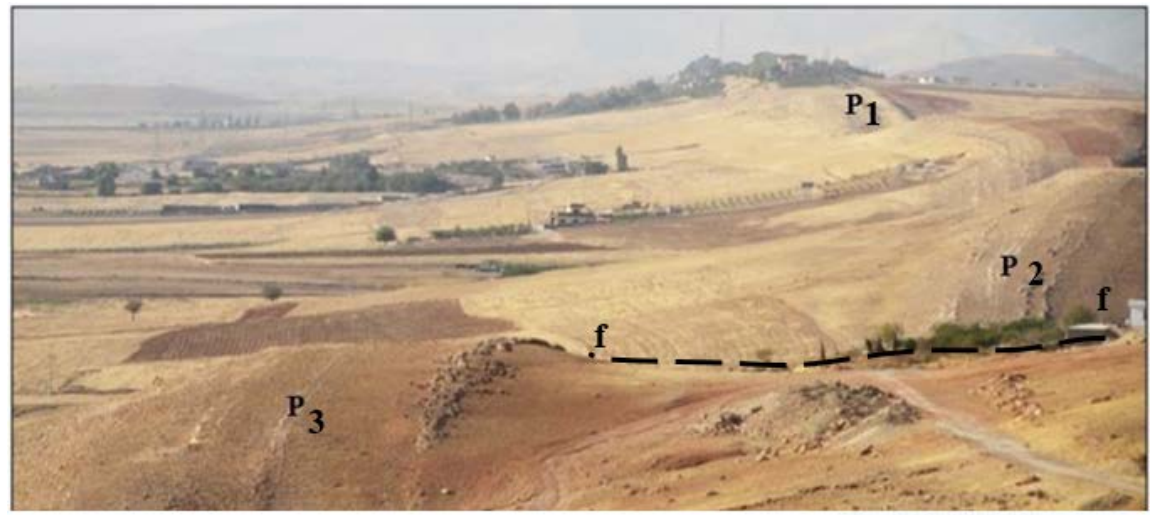

Figure 2. The Pila Spi Formation (P) along the southwestern limb of the Hareer anticline. Note the faulted and overturned beds (P3), P2 is normal bed, P3 is a vertical bed, $\mathrm{f}-\mathrm{f}$ is the fault line.
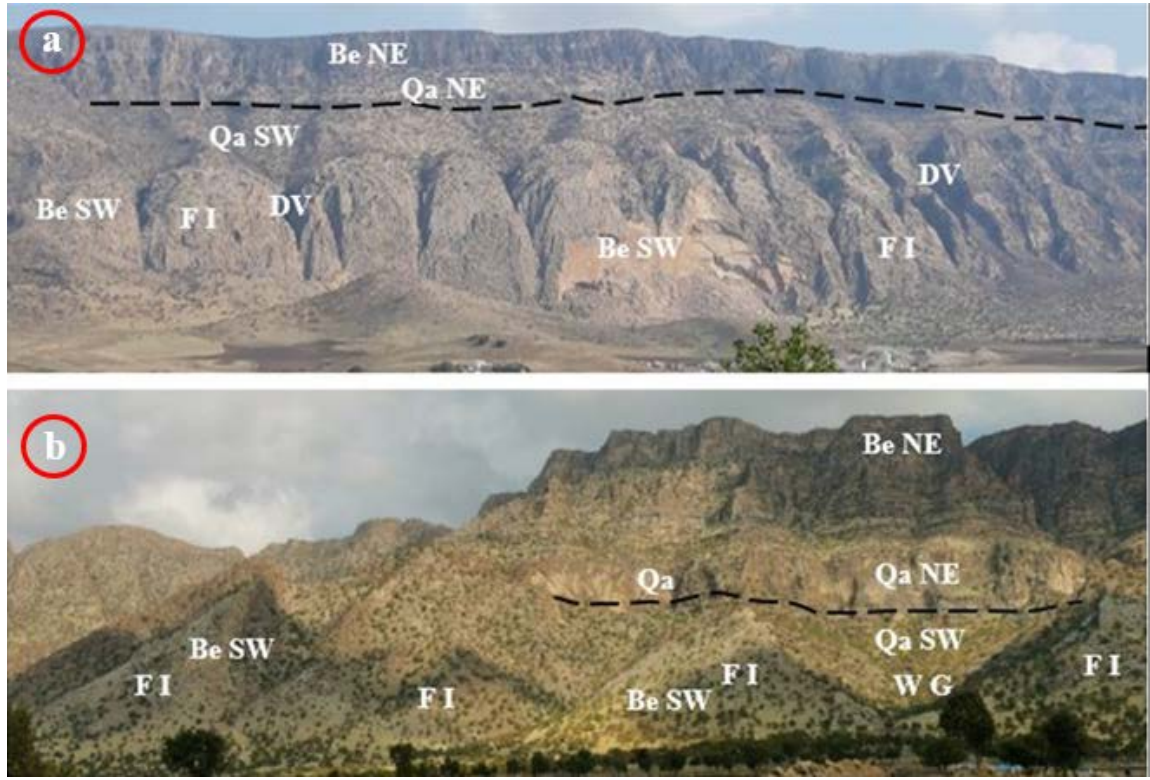

Figure 3. The southwestern limb of the Hareer anticline. Top) Fault scarp (Dashed black line) and deeply cut valleys (DV), Bottom) Details of the low angle thrust fault. Also note the flat irons (F I), wine glasses (W G). Be NE and Be SW (Bekhme Formation, NE limb and SW limb, respectively, Qa NE and Qa SW Qamchuqa Formation, NE limb and SW limb, respectively). 


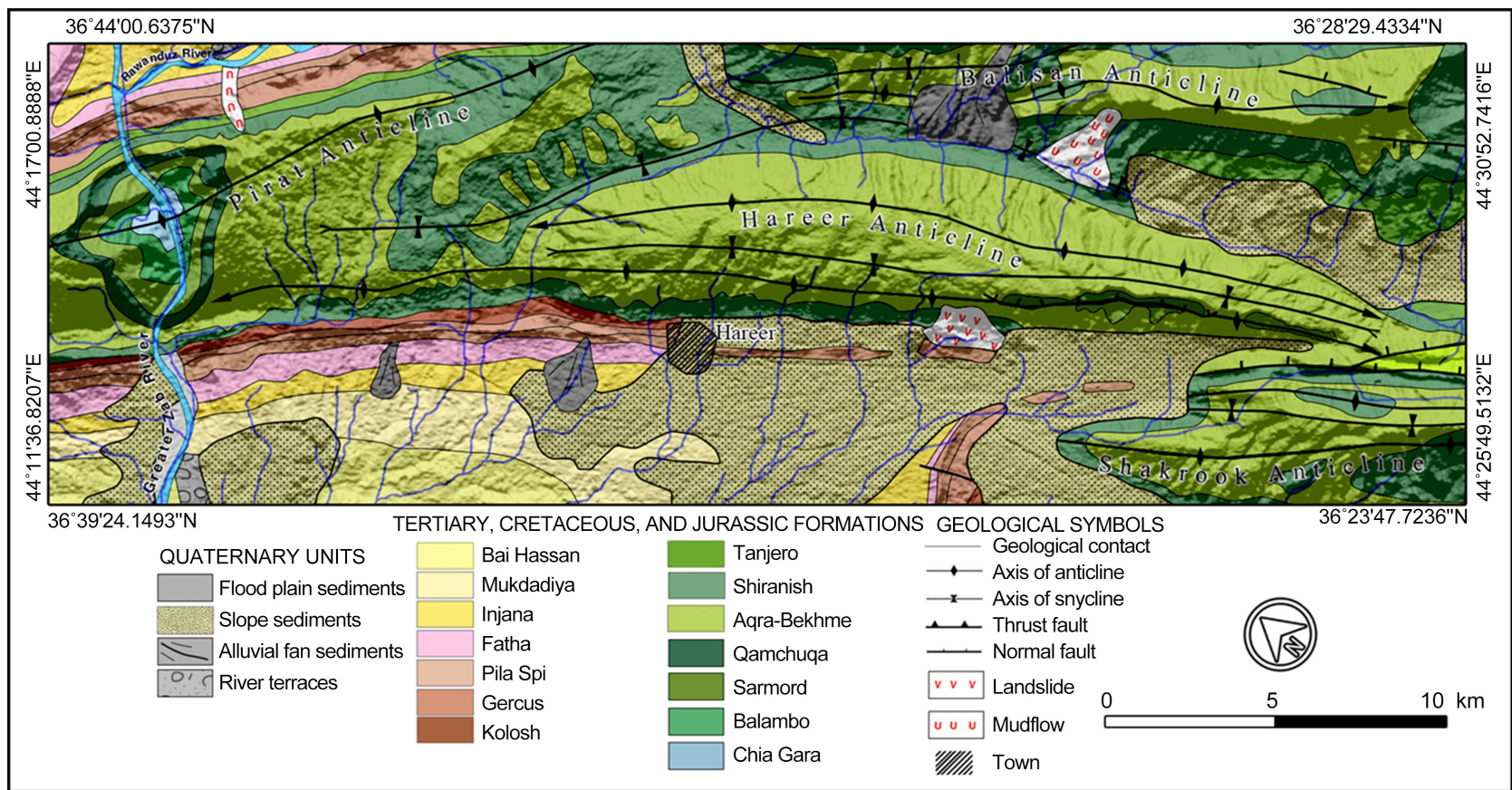

Figure 4. Geological map of Hareer anticline and near surrounding (Modified from [10]).

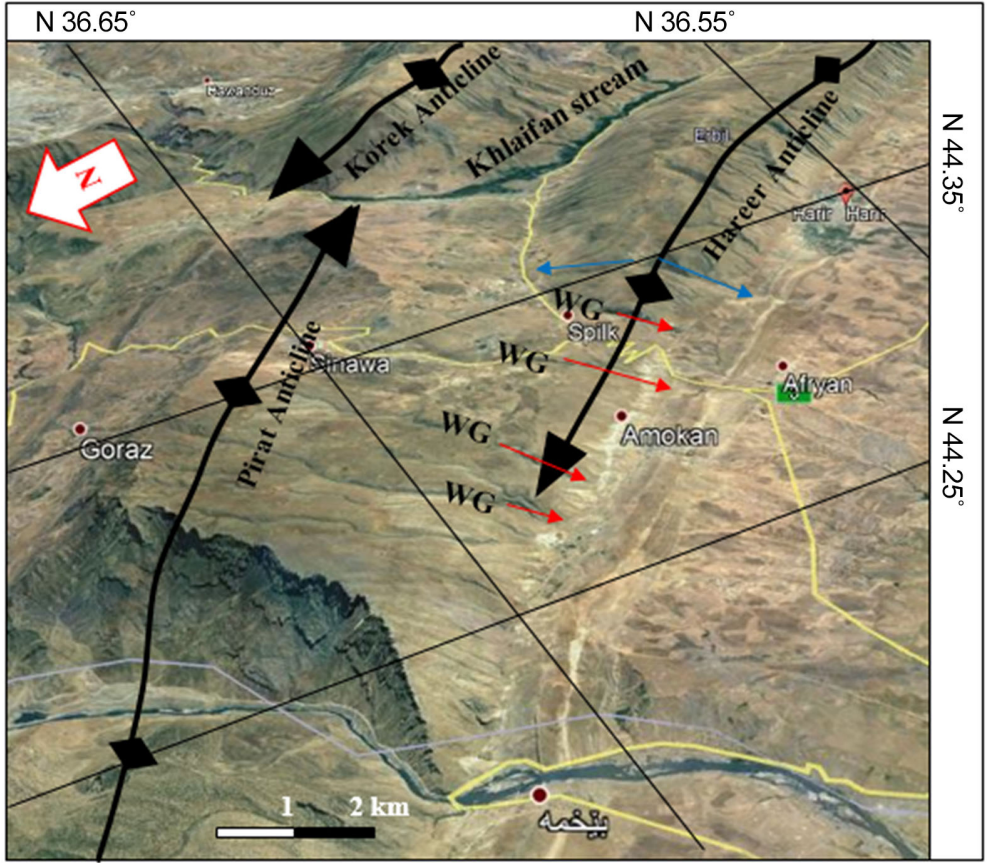

Figure 5. Satellite image showing the northwestern plunge of the Hareer anticline. Note the effect of the plunge of the Hareer anticline on the southwestern limb and southeastern plunge of the Pirat anticline. Also note the 4 wind gaps (WG), the converted wind gap (marked by two blue arrows), the straight edge of the southwestern limbs of the Hareer and Pirat anticlines, and the Greater Zab River shifted inside Bekhme Gorge.

Moreover, the existence of a minor fold northwards of the main anticlinal axis (Figure 1) has contributed to forming a box shape with a very steep southwes- 
tern limb which is dissected by very deeply cut valleys, which starts immediately southwest of the axis and some of them are even northeast of the axis (Figure 1). The south western limb is very steep with the dip of the beds ranging from $\left(47^{\circ}-\right.$ $84^{\circ}$ ), whereas the north eastern limb is gentler with the dip of the beds ranging from $\left(22^{\circ}-34^{\circ}\right)$.

\subsection{Stratigraphy}

The exposed formations along the Hareer anticlines are mentioned briefly from the oldest to the youngest depending on Sissakian and Al-Jibouri [26]. The geological map of the anticline is presented in Figure 4.

- Qamchuqa Formation (Lower Cretaceous): The formation is exposed only in some deeply cut valleys and along a fault scarp within the southwestern limb (Figure 3 and Figure 4). It consists of massive and thickly bedded dolostone and limestone. The exposed thickness is about $75 \mathrm{~m}$;

- Bekhme Formation (Upper Cretaceous): The formation forms the bulk of Hareer Mountain (anticline) (Figure 3 and Figure 4). It consists of well bedded and thickly bedded dolostone and limestone. The thickness of the formation is about $115 \mathrm{~m}$;

- Shiranish Formation (Upper Cretaceous): The formation is poorly exposed (Figure 4). It includes two parts; the lower part consists of well bedded white marly limestone, whereas the upper part consists of dark bluish grey papery marl. The thickness of the formation is $85 \mathrm{~m}$;

- Tanjero Formation (Upper Cretaceous): The formation is exposed only in the northeastern limb (Figure 4). It consists of dark greenish grey fine clastics. The thickness of the formation is $140 \mathrm{~m}$;

- Kolosh Formation (Paleocene): The formation is poorly exposed (Figure 4). It consists of black fine clastics. The thickness of the formation is $95 \mathrm{~m}$;

- Gercus Formation (Eocene): The formation is poorly exposed (Figure 4). It consists of reddish brown fine clastics. The thickness of the formation is 85 $\mathrm{m}$;

- Pila Spi Formation (Upper Eocene): The formation is poorly exposed (Figure 4). It is highly dissected by faults and locally is overturned (Figure 2). It consists of well bedded dolostone and limestone with rare marl beds. The thickness of the formation is $25 \mathrm{~m}$;

- Fatha Formation (Middle Miocene): The formation is poorly exposed (Figure 4). It consists of thick reddish brown claystone with thin limestone and gypsum. The thickness is $130 \mathrm{~m}$;

- Injana Formation (Upper Miocene): The formation is poorly exposed (Figure 4). It consists of thick reddish brown claystone and sandstone in a cyclic nature. The thickness is $150 \mathrm{~m}$;

- Mukdadiya Formation (Upper Miocene-Pliocene): The formation is poorly exposed (Figure 4). It consists of thick grey claystone and sandstone in a cyclic nature. The thickness is about $660 \mathrm{~m}$; 
- Bai Hassan Formation (Pliocene-Pleistocene): The formation is poorly exposed (Figure 4). It consists of thick brown claystone and conglomerate in a cyclic nature. The thickness is $1000 \mathrm{~m}$;

- Quaternary Sediments: The main sediments are those of alluvial fans, slope sediments, terraces and valley fill sediments.

\subsection{Geomorphology}

The main geomorphological features within the Hareer anticline are very old alluvial fans (Figure 6), flat irons (Figure 3) and landslides (Figure 7) [27]. They are developed along the southwestern limb only. This is attributed to very steep beds and presence of soft rocks between the Qamchuqa and Bekhme formations. Both landslides and alluvial fans are believed to be Early Pleistocene [27]. The highest peak along the Hareer Mountain is $1414 \mathrm{~m}$ (a.s.l.).

The southwestern limb of the Hareer anticline is characterized by very deep canyon like valleys (Figure 3). This is attributed to very steep beds along this limb and the axis of the anticline being close to the upper most part of the limb. Wine glasses (Figure 3) are developed along the southwestern limb. The anticline is also characterized by water and wind gaps (Figure 2 and Figure 8), and whale-back shapes (Figure 1), this is attributed to the wide hinge zone which narrows at both plunging areas.

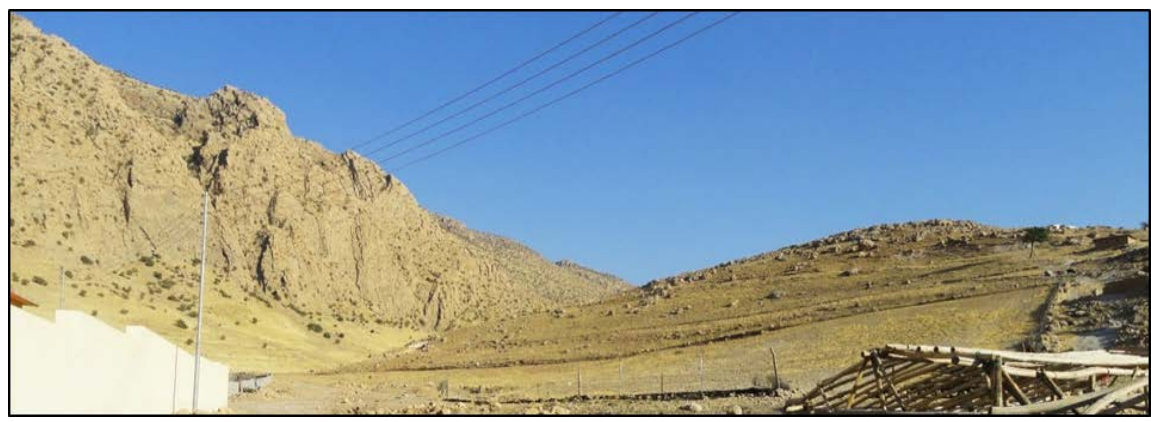

Figure 6. Very old alluvial fan which is already separated from the Hareer anticline because of severe water erosion, due to very steep beds and deeply cut valleys (Photo axis towards NE).

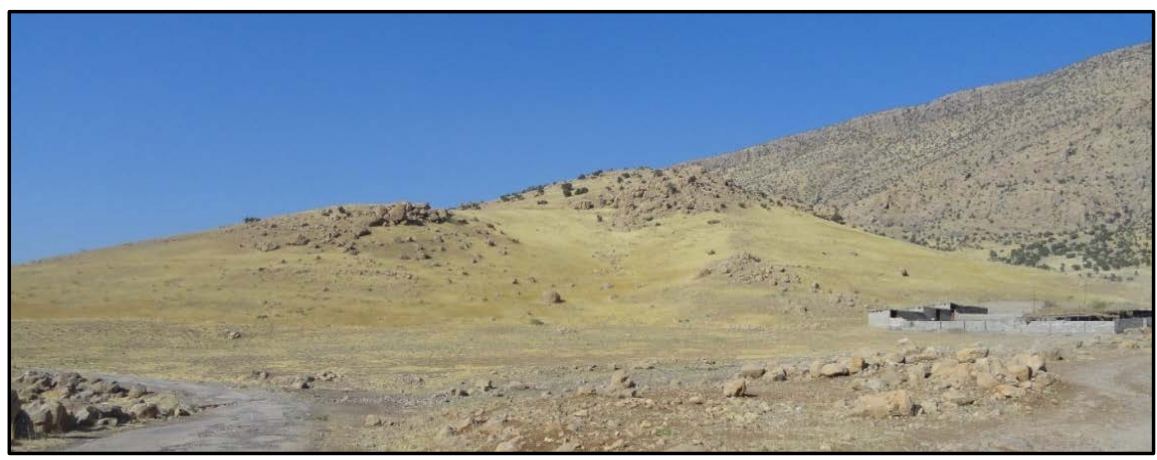

Figure 7. Very old landslide along the southwestern limb of the Hareer anticline, showing the sliding mass (Photo axis towards NW). 


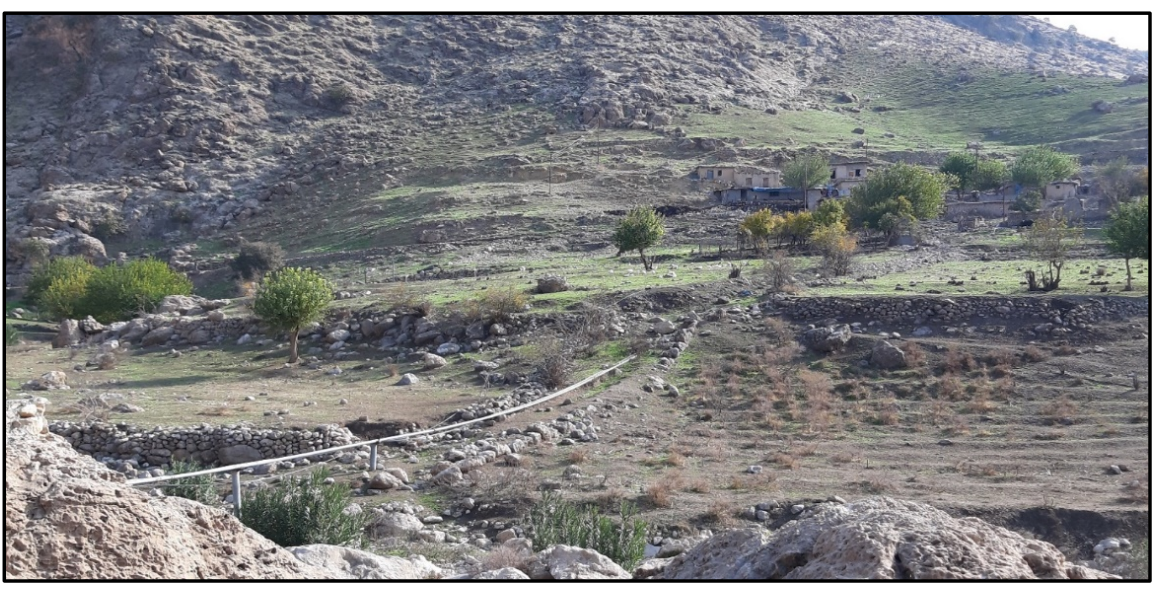

Figure 8. Outlet of a wind gap developed along the southwestern limb of the Hareer anticline. Note the remnants of the abandoned alluvial fan, which reaches near to the houses.

\section{Results}

The Hareer anticline is one of the main anticlines in the Kurdistan Region, in the northern part of Iraq. It forms the contact between the High Folded and Low Folded zones [21]. The length and width of the anticline is $25 \mathrm{~km}$ and $4.8 \mathrm{~km}$, respectively. The anticline has a unique abnormal form, especially at both the northwestern and southeastern plunges. It forms a left hand en-echelon plunge with the Pirat anticline (Figure 1 and Figure 2) [13]. Eight topographic crosssections were constructed (Figure 9), seven of them are across the anticline at NE-SW directions; whereas one is constructed across both plunges in a NW-SE direction.

It is very clear from the constructed seven cross-sections, that only cross-sections Nos. 4 and 5 show a normal anticlinal form, whereas in the others the abnormal shape of the anticline can be seen. Moreover, cross-section No. 5 clearly shows the presence of a saddle along the hinge zone, indicating the presence of two anticlinal axes. In the cross-sections Nos. 1, 2 and 3 which represent the northwestern plunge area, it is clear that there is no anti-form, especially in cross-section No. 2. The present anti-form in cross-sections Nos. 1 and 3 are the southeastern plunge of the Pirat anticline which forms an en-echelon form with the Hareer anticline (Figure 1, Figure 4 and Figure 5). In cross-sections Nos. 6 and 7, the southeastern plunge of the Hareer anticline shows a clear change in the width of the anticline, as compared to the cross-sections of Nos. 4 and 5.

The longitudinal cross-section, from northwestern plunge to the southeastern plunge (Cross-section L1 - L2, Figure 9) shows clear minor irregularities along the axial zone. The deepest one is a water gap (GZR, Figure 9) represented by Bekhme Gorge (Figure 1, Figure 2, Figure 4) at the extreme northwestern part of the anticline. Before this water gap, there is another deep topographic form near Spilk (Point No. 5, Figure 9), and most probably it represents a very old water gap which forms nowadays opposite the sides valleys (Figure 10). This is attributed to a high rate of upward movement as compared to the rate of stream 


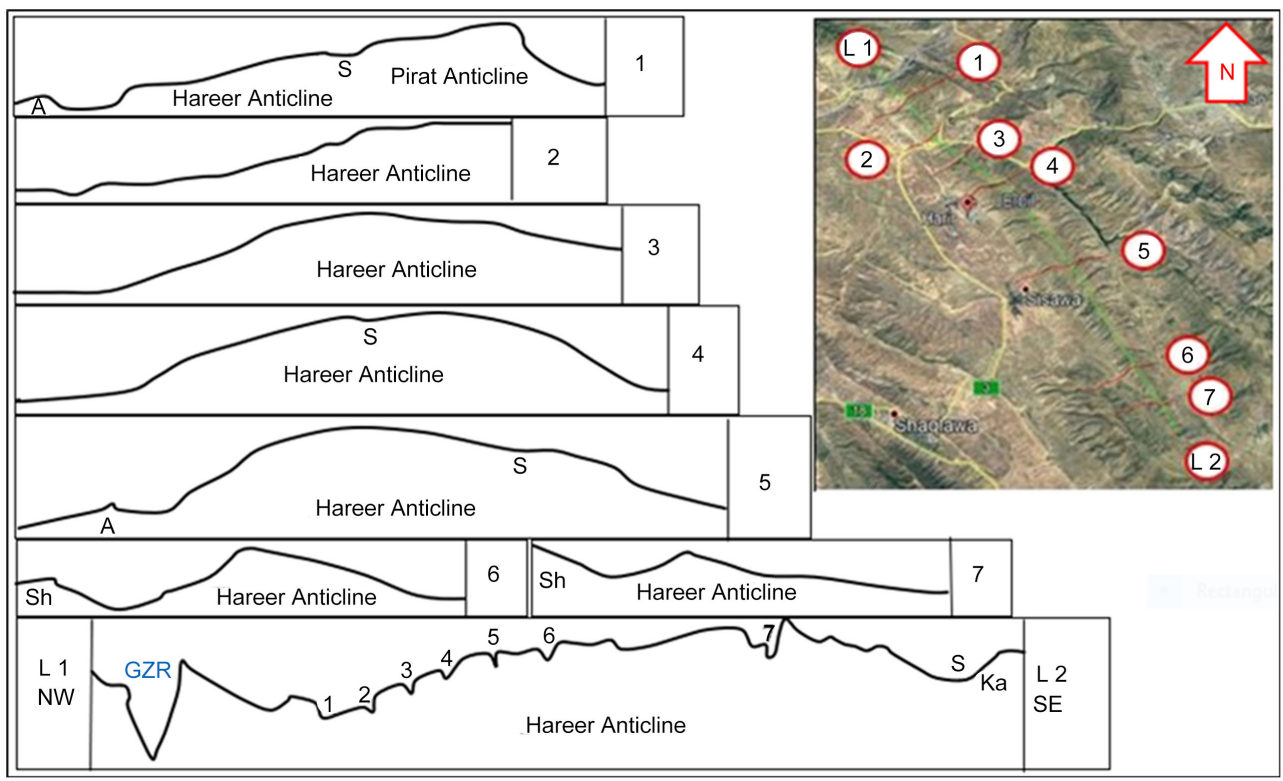

Figure 9. The Hareer anticline with seven topographic cross-sections and one longitudinal section. Note the abnormal shapes of both plunges, the large difference in the widths of plunge areas as compared to the mid part of the anticline. Also note the shallow saddle at cross-section No. 5, due to the presence of two anticlinal axes which give box-fold and whale-back shapes to the anticline. A refers to the ridge of the Pila Spi Formation, GZR refers to the Greater Zab River, S represents a saddle, $\mathrm{K}$ refers to Kamost anticline. For other details, refer to the text (5.1).

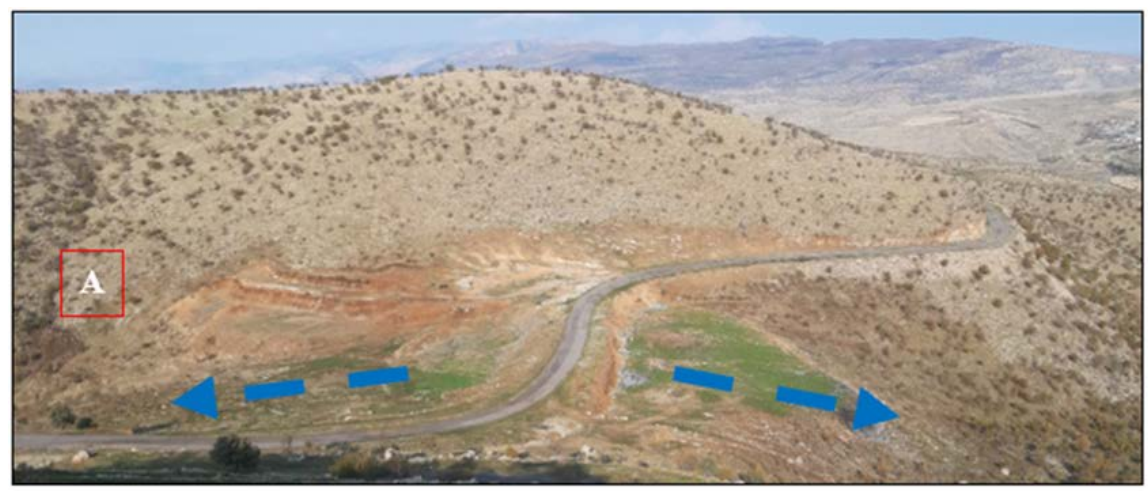

Figure 10. Water divide point between two valleys (blue arrows) that previously were one stream crossing the Hareer anticline. At point A, a clear dipping of the beds indicates a saddle along the main axis of the Hareer anticline (Point $E$ in Figure 2 and Figure 9).

incision at the area, besides the presence of a gentle saddle along the main axis of the Hareer anticline (Point A, Figure 9). The last deep topographic form along the longitudinal cross-section L1 - L2 (Point S, Figure 9) is another wind gap located at the southeastern plunge of the Hareer anticline. However, this can be formed due to the main thrust fault which runs parallel to the anticline.

\section{Discussion}

\subsection{Shape of the Hareer Anticline}

The northwestern plunge of the Hareer anticline was east of Spilk (Figure 1 and 
Figure 2) where the Khlaifan stream was flowing southwards around the plunge of the Hareer anticline; as indicated from the existence of a large old alluvial fan south of the anticline (Figure 11). By the continuous growth of the Hareer anticline northwest wards; as indicated from the presence of five wind gaps (Figure 2, Figure 9 and Figure 12), the Khlaifan stream shifted to its nowadays geographic location, where it flows between the plunge areas of the Pirat and Korek anticlines (Figure 1 and Figure 5) [17]. The northwest wards growth is still continuous, and this is indicated by shifting of the axis of the Pirat anticline more northwards forming en-echelon pattern with the Hareer anticline (Figure 1 and
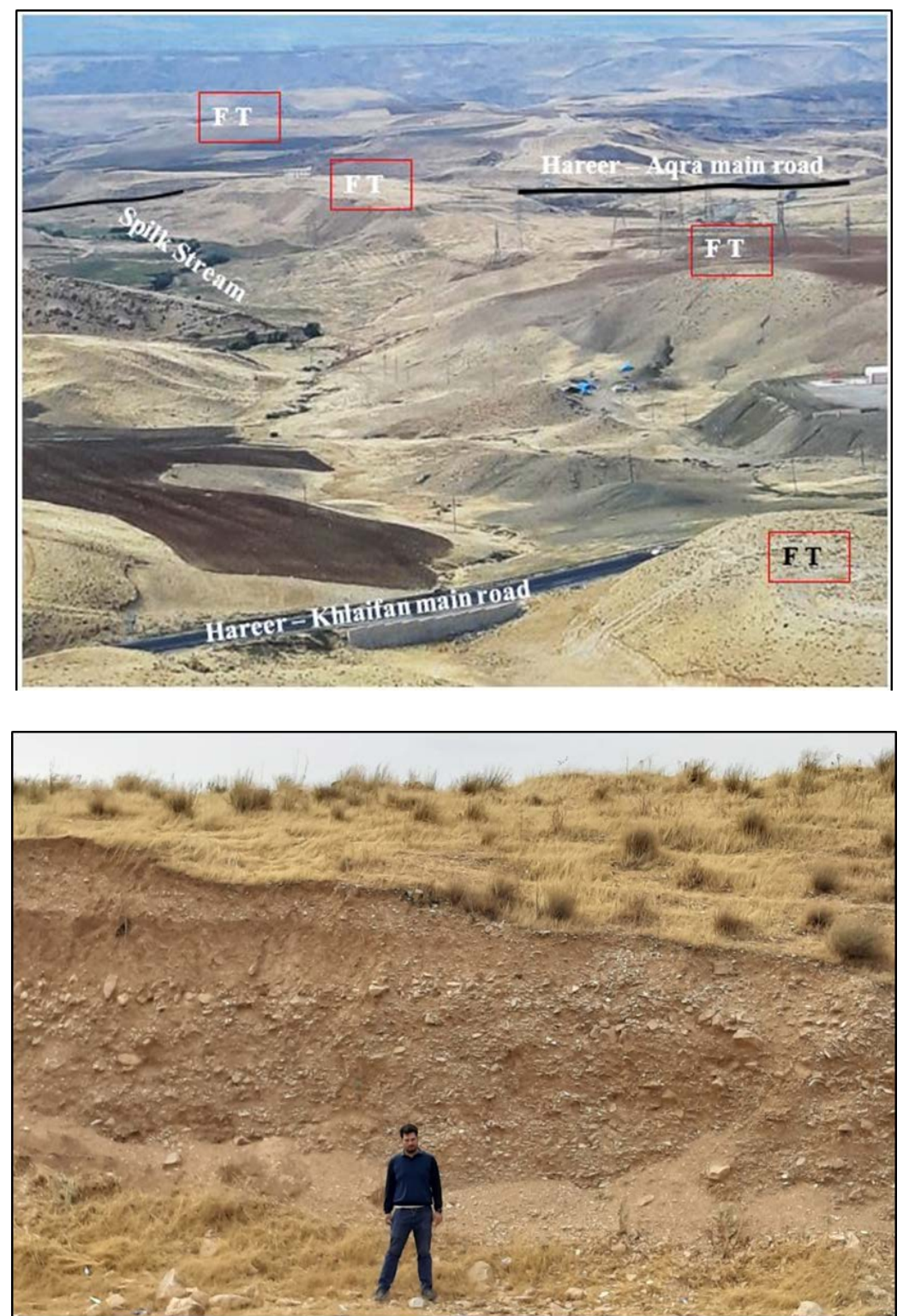

Figure 11. Top) Spilk Alluvial fan, general view. Note the flat top areas (FT) representing remnants of the abandoned alluvial along the right bank of the stream (Photo axis towards SW), Bottom) Details of the Spilk fan. Note the presence of more than one level of gravel, the higher level is finer indicating a decrease in the depositional energy of the fan (Photo axis towards SW). 


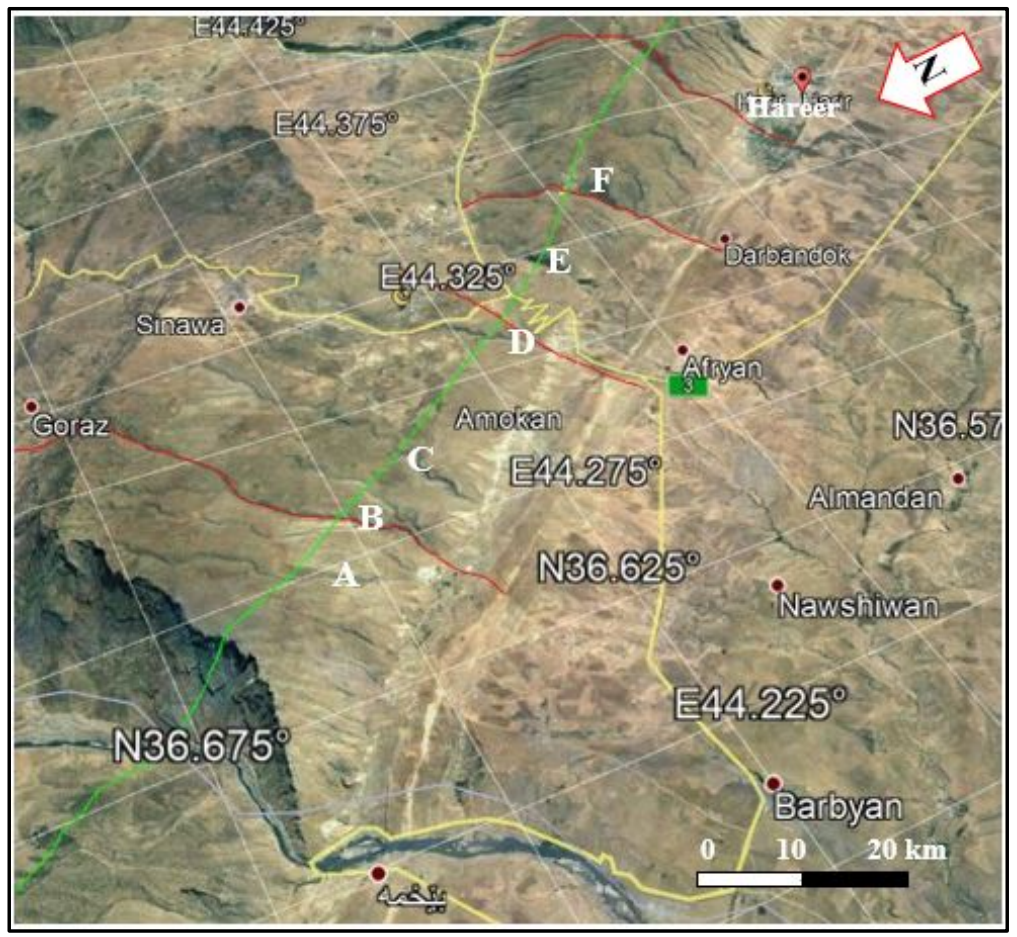

Figure 12. Satellite image of the Hareer anticline. Note the 5 wind gaps at points $\mathrm{A}, \mathrm{B}, \mathrm{C}, \mathrm{D}$, and $\mathrm{E}$ and the other possible wind gap near the Darbandok village (Point F). The green and red lines are the locations of some of the cross-sections presented in Figure 9.

Figure 2) and the abnormal form of the northwestern plunge of the Hareer anticline (Figure 1, Figure 2 and Figure 9). According to Cowie [28], aligned fold segments are likely to grow at the expense of other, non-aligned segments, by a positive feedback in the stress changes around the structure. Therefore, fold segments grow in length and divert drainage around their ends. This is what happened with the Khlaifan stream.

We have constructed 7 topographic cross-sections (Nos. 1 - 7) and one longitudinal section (L1 - L2) along the axis of the anticline (Figure 9) to show the abnormal shape of the anticline.

Section 1: There is a very low saddle at point $S$; about $8 \mathrm{~m}$ between the Hareer and Pirat anticlines. Section 2: Shows the southwestern limb of the Hareer anticline. Section 3: Shows the cross-section of the Hareer anticline. Section 4: Shows a very gentle saddle, about $5 \mathrm{~m}$ between the two axes of Hareer anticline. Section 5: Shows a very gentle saddle, about $6 \mathrm{~m}$ between the two axes of the Hareer anticline, and at point A, the outcrops of the Pila Spi Formation have formed a ridge of $33 \mathrm{~m}$ height. Section 6: Shows the narrow width of the Hareer anticline near the southeastern plunge, and point A represents the northeastern limb of the Shakrook anticline. Section 7: Shows the southeastern plunge area; very narrow due to a main thrust fault which runs between the Hareer and Shakrook anticlines (Figure 1 and Figure 4).

Section L1 - L2: Shows the wind gaps 1, 2, 3, 4, 5 and the possible wind gap at 
point 6 (Figure 9). Also, there are deep cut valleys. At point 7, there is a large wine glass form (Figure 3). Point $S$ is the saddle between the Hareer and Kamosk anticlines, and point $\mathrm{K}$ represents the northwestern plunge of the Kamosk anticline. The increasing depth of the water gaps towards the NW, indicates the growth of the Hareer anticline, northwest wards. This phenomenon was recognized by Burbank and Anderson [11] and Ramsey et al. [4]. Another indication for the continuous growth of the Hareer anticline is the presence of a possible wind gap near Darbandok village (Figure 5, Figure 9 and Figure 12, Point E). Nowadays it is not a wind gap; it is converted into two valleys flowing in the opposite directions to each other (Figure 10) due to the continuous upwards growth of the anticline.

The presence of en-echelon fold and an abandoned alluvial fan are good indications for the lateral growth of anticlines [4] [11] [14] [16]. Moreover, the whale-back shape of the Hareer anticline is another indication for its lateral growth. Such form is confirmed to be an indication for the lateral growth by Burbank and Pinter [29] and Burbank and Anderson [11].

The last indication for the continuous up wards' growth of the Hareer anticline and exhibiting abnormal shape, especially at the northwestern plunge area, is the edge of the southwestern limbs of the Hareer and Pirat anticlines. Although they exhibit a clear en-echelon fold, their southwestern limbs form a continuous straight line (Figure 1, Figure 2, Figure 4 and Figure 12). This is not a normal form for en-echelon plunging; since there should be a syn-form between them; accordingly, the edges of their limbs should not form a straight line [12] [13] as it is the case in the Hareer and Pirat anticlines.

\subsection{Rate of Incision of Spilk Stream}

The elevation difference between the floor of the feeder channel of the Spilk alluvial fan and its nowadays base is $35 \mathrm{~m}$ (Figure 11). The thickness of the abandoned alluvial fan is $18 \mathrm{~m}$. The age of the alluvial fans is most probably Holocene [30] [31], because it is covered by soil and not calcrete as the case with other old alluvial fans (Figure 6). This means it was deposited during 11,700 years (Holocene, [32]). Therefore, the rate of the deposition of the abandoned Spilk alluvial fan will be $0.154 \mathrm{~m} / 100$ years $(18 \mathrm{~m} \times 100 / 11,700)$. Whereas the rate of the incision of the Spilk stream (the feeder channel) since the Holocene, is about 0.3 $\mathrm{m} / 100$ years $(35 \mathrm{~m} \times 100 / 11,700$ years $)$.

\section{Conclusions}

The authors conclude that the Hareer anticline has an abnormal shape, especially at the northwestern plunge area. This is attributed due to many interpreted and recognized geomorphological and structural forms, mainly due to its lateral and upward growth. Moreover, the anticline has two axes with a very gentle saddle in between, which gives the anticline a box-fold shape. Moreover, the hard rocks of the Bekhme Formation form the carapace of the Hareer Mountain (an- 
ticline) with the deeply cut valleys, giving the anticline a whale-back shape. Although there is a right-hand en-echelon plunge with the Pirat anticline, the southwestern limb of both the Hareer and Pirat anticlines forms a continuous straight ridge without any bulge, which usually exists in en-echelon plunges. This is a unique case in the whole anticlines within the Zagros Fold-Thrust Belt in the Iraqi Kurdistan Region. The northwestern plunge area of the Hareer anticlines almost merges with the southeastern plunge area of the Pirat anticlines; near Bekhme Gorge. This gives the impression that the two anticlines are merging together at that specific area.

The rate of incision of the Spilk stream is calculated to be $0.3 \mathrm{~m} / 100$ years. Many indications were recognized which indicate the growth of the Hareer anticline. Among them are: en-echelon plunging, existence of wind gaps, whale-back shape, the presence of abandoned Spilk alluvial fan, and the straight edge of the southwestern limbs of the Hareer and Pirat anticlines; although they exhibit en-echelon plunging.

\section{Acknowledgements}

The authors would like to express their sincere thanks to the authorities in the University of Kurdistan Hewler, Erbil, Iraq and the Lulea University of Technology, Lulea Sweden for their continuous given help for performing the current work. Thanks are extended to the esteemed reviewers for their constructive comments.

\section{Conflicts of Interest}

The authors declare no conflicts of interest regarding the publication of this paper.

\section{References}

[1] Berberian, M. (1993) Tectonic Map of Iran Scale 1:1500000. In: Continental Deformation in the Iranian Plateau, Contribution to the Seismotectonics of Iran, Part IV Geological Survey Iran, Tehran, $52 \mathrm{p}$.

[2] Blanc, E.J.P., Allen, M.B., Inger, S. and Hassani, H. (2003) Structural Styles in the Zagros Simple Folded Zone, Iran. Journal of Geological Society London, 160, 401-412. https://doi.org/10.1144/0016-764902-110

[3] Bennett, E., Youngson, J., Jackson, J., Norris, R., Raisbeck, G., Yiou, F. and Fielding, E. (2005) Growth of South Rough Ridge, Central Otago, New Zealand: Using in Situ Cosmogenic Isotopes and Geomorphology to Study an Active, Blind Reverse Fault. Journal of Geophysics Researches, 110, B02404. https://doi.org/10.1029/2004JB003184

[4] Ramsey, L.A, Walker, R.T. and Jackson, J. (2008) Fold Evolution and Drainage Development in the Zagros Mountains of Fars Province, SE Iran. Basin Research, 20, 23-48. https://doi.org/10.1111/j.1365-2117.2007.00342.x

[5] Ghafur, A.A., Sissakian, V.K., Abdulhaq, H.A. and Omer, H.O. (2019) Aqra Anticline: A Growing Structure in the Iraqi Kurdistan Region. ARO-The Scientific Journal of Koya University, 7, 27-33. https://doi.org/10.14500/aro.10535 
[6] Sissakian, V.K., Abdulhaq, H.A., Ghafur, A.A. and Omer, H.O. (2020) Deducing the Lateral Growth of Handreen, Zozik and Tanoun Anticlines, Iraqi Kurdistan Region, Using Geomorphological Features. Iraqi Geological Journal, 53, 1-20. https://doi.org/10.46717/igj.53.1C.1Rx-2020-04-01

[7] Sissakian, V.K., Ghafur, A.A., Abdulhaq, H.A. and Omer, H.O. (2020) Indicating the Tectonic Origin of Gara and Mateen Anticlines Using Geomorphological and Structural Forms, Iraqi Kurdistan Region. UKHJSE, 4, 84-100. https://doi.org/10.25079/ukhjse.v4n2y2020.pp84-100

[8] Alavi, M. (2004) Regional Stratigraphy of the Zagros Fold-Thrust Belt of Iran and Its Proforeland Evolution. American Journal of Science, 304, 1-20. https://doi.org/10.2475/ajs.304.1.1

[9] Allen, M., Jackson, J. and Walker, R. (2004) Late Cenozoic Reorganisation of the Arabia-Eurasia Collision and the Comparison of Short-Term and Long-Term Deformation Rates. Tectonics, 23, TC2008. https://doi.org/10.1029/2003TC001530

[10] Sissakian, V.K. and Fouad, S.F. (2015) Geological Map of Iraq, 4th Edition, Scale 1: 1000000. Iraqi Bulletin of Geology and Mining, 11, 9-18.

[11] Burbank, D.W. and Anderson, R.S. (2001) Tectonic Geomorphology. Blackwell Scientific Publications, Oxford, 274 p.

[12] Fossen, H. (2010) Structural Geology. Cambridge University Press, Cambridge, 463 p. https://doi.org/10.1017/CBO9780511777806

[13] Campbell, J.D. (1958) En-Echelon Folding. Economic Geology, 53, 448-472. https://doi.org/10.2113/gsecongeo.53.4.448

[14] Keller, E.A. and Pinter N. (2002) Active Tectonics: Earthquakes, Uplift, and Landscape. 2nd Edition, Prentice Hall, Upper Saddle River, 359 p.

[15] De Vera, J., Gines, J., Oehlers, M., Mcclay, K. and Doski, J. (2009) Structure of the Zagros Fold and Thrust Belt in the Kurdistan Region, Northern Iraq. Trabajos de Geología, Universidad de Oviedo, 29, 213-217.

[16] Burtscher, A.Y., Frehner, M. and Grasemann, B. (2012) Tectonic Geomorphological Investigations of Antiforms Using Differential Geometry: Permam Anticline, Northern Iraq. Journal of American Association of Petroleum Geologists, 96, 301-316. https://doi.org/10.1306/06141110204

[17] Sissakian, V.K. and Abdul-Jabbar, M.F. (2010) Morphometry and Genesis of the Main Transversal Gorges in North and Northeast Iraq. Iraqi Bulletin of Geology and Mining, 6, 95-120.

[18] Sissakian, V.K., Abdul Jabbar, M.F., Al-Ansari, N. and Knutson, S. (2015) Development of Galley Ali Beg Gorge, Rawnadouz Area, North Iraq. Engineering, 7, 16-30. https://doi.org/10.4236/eng.2015.71002

[19] Omar, A.A. and Syan, S.H. (2016) Construction of a Structural Model for Harir Anticline within Zagros Fold-Thrust Belt, Kurdistan of Iraq. ZANCO Journal of Pure and Applied Sciences, Journal of Salahaddin University-Erbil, 28, 90-105.

https://doi.org/10.21271/ZJPAS.28.6.12

[20] Le Garzica, E, Vergésb, J., Sapinc, F., Saurab, E., Meressec, F., Ringenbachc, J.C. and Libal, A. (2017) Evolution of the NW Zagros Fold-and-Thrust Belt in Kurdistan Region of Iraq from Balanced and Restored Crustal-Scale Sections and Forward Modeling. Journal of Structural Geology, 124, 51-69. https://doi.org/10.1016/j.jsg.2019.04.006

[21] Fouad, S.F. (2015) Tectonic Map of Iraq, 3rd Edition, Scale 1: 1000000. Iraqi Bulletin of Geology and Mining, 11, 1-8. 
[22] Jassim, S.Z. and Goff, J.C. (2006) Geology of Iraq. Dolin, Prague and Moravian Museum, Brno, $361 \mathrm{p}$.

[23] Burberry, C.M. (2015) The Effect of Basement Fault Reactivation on the Triassic-Recent Geology of Kurdistan, North Iraq. Journal of Petroleum Geology, 38, 37-58. https://doi.org/10.1111/jpg.12597

[24] Obaid, A.K. and Allen, M.B. (2017) Landscape Maturity, Fold Growth Sequence and Structural Style in the Kirkuk Embayment of the Zagros, Northern Iraq. Tectonophysics, 717, 27-40. https://doi.org/10.1016/j.tecto.2017.07.006

[25] Hessami, K., Koyi, H.A. and Talbot, C.J. (2001) The Significance of Strike-Slip Faulting in the Basement of the Zagros Fold and Thrust Belt. Journal of Petroleum Geology, 24, 5-28. https://doi.org/10.1111/j.1747-5457.2001.tb00659.x

[26] Sissakian, V.K. and Al-Jibouri, B.M. (2014) Stratigraphy. In: Geology of the High Folded Zone. Iraqi Bulletin of Geology and Mining, Special Issue, No. 6, 73-161.

[27] Sissakian, V.K., Mustafa, H.I., Sidiq, S.A., Haris, G.K., Al-Ansari, N. and Knutson, S. (2016) Age Estimation and Causes of Landslides in Hareer Anticline, Central Northern Part of Iraq. Journal of Earth Sciences and Geotechnical Engineering, 7, 25-43.

[28] Cowie, P.A. (1998) A Healing-Reloading Feedback Control on the Growth Rate of Seismogenic Faults. Journal of Structural Geology, 20, 1075-1087. https://doi.org/10.1016/S0191-8141(98)00034-0

[29] Burbank, D.W. and Pinter, N. (1999) Landscape Evolution: The Interactions of Tectonics and Surface Processes. Basin Research, 11, 1-6. https://doi.org/10.1046/j.1365-2117.1999.00089.x

[30] Yacoub, S.Y., Othman, A.A. and Kadhum, T.H. (2011) Geomorphology. In: Geology of the Low Folded Zone. Iraqi Bulletin of Geology and Mining, Special Issue, No. 5, 7-38.

[31] Sissakian, V.K., Kadhim, T.H. and Abdul Jab’bar, M.F. (2014) Geomorphology of the High Folded Zone. Iraqi Bulletin of Geology and Mining, Special Issue, No. 6, 47-56.

[32] IUGS (International Union of Geological Sciences) (2012) Geological Time Scale. Brisbane. 